JOURNAL OF SECURITY AND SUSTAINABILITY ISSUES

ISSN 2029-7017 print/ISSN 2029-7025 online

2019 September Volume 9 Number 1

http://doi.org/10.9770/jssi.2019.9.1(8)

\title{
Scopus
}

\section{SECURITY OF ORGANIZATIONAL CHANGES VIA OPERATIONAL INTEGRATION: ENSURING METHODOLOGY}

\author{
Svetlana Drobyazko, Olena Potyshniak², Natalia Radionova ${ }^{3}$, Serhii Paranytsia ${ }^{4}$, Yuliia Nehoda ${ }^{5}$ \\ $1^{*}$ European academy of sciences, 111 New Union Street, Coventry, United Kingdom \\ ${ }^{2}$ Kharkiv Petro Vasylenko National Technical University of Agriculture, st. Alchevskys, 44, Kharkov, Ukraine, 61002 \\ ${ }^{3}$ Kyiv National University of Technologies and Design, Nemyrovycha-Danchenka Street, 2, Kyiv, 01011, Ukraine \\ ${ }^{4}$ National University of the State Fiscal Service of Ukraine, 31, Universitetskaya Street, Irpin, 08205, Ukraine \\ ${ }^{5}$ National University of Life and Environmental Sciences of Ukraine, Heroiv Oborony Str. 15, Kyiv, 03041, Ukraine
}

E-mail: ${ }^{1 *}$ drobyazko.s.i@gmail.com

Received 16 January; accepted 30 June 2019; published 30 September 2019

\begin{abstract}
The concept and the need of organizational changes in the corporate environment in order to ensure a lasting effect of economic and strategic security were determined. The methodology for conducting organizational changes based on the use of optimal operational integration, which forms a decomposition of the company's development goals and forms the field of economic security was proposed. The model analysis of ensuring effective organizational security and operational integration of the functional units of the company was carried out.
\end{abstract}

Keywords: company security, operational integration, organizational changes, company value, business development strategy, functional units, management process

Reference to this paper should be made as follows: Drobyazko, S.; Potyshniak, O.; Radionova, N.; Paranytsia, S.; Nehoda, Y. 2019. Security of organizational changes via operational integration: ensuring methodology, Journal of Security and Sustainability Issues 9(1): 91-105. http://doi.org/10.9770/jssi.2019.9.1(8)

JEL Classifications: C51, L20, M20

\section{Introduction}

Under the conditions of globalization of the economy, which are constantly changing, such as unevenness of the functioning of a market economy, fluctuations in production and sales, emergence of deep production recessions, the possibility of a crisis increases, which should be considered as some general pattern and a threat to economic security. In the market economy conditions, crisis situations inevitably arise both for the system as a whole and for individual economic entities. However, the adaptation of most of them to market conditions is slow process. One of the real ways for a company to overcome the crisis and increase business efficiency is organizational change - the transformation of all key areas of operation. Organizational changes are deliberate changes in an enterprise caused by external events, implemented through various projects (business projects, innovations). Examples of major changes can be mastering of improved technology, creation of a new product, improvement of the organizational structure and integration corporate processes. 


\section{Literature Survey}

In the scientific community, the works of such scientists as (Bhojraj \& Sengupta 2003; Cawsey \& Deszca 2007; Isern \& Pung 2007; Kotter 2012; Sams, 2001; Wit \& Meyer 2005; Zahavi \& Lavie 2013) are well known, which describe in detail and model various aspects of organizational changes. But only extensive methodological studies of ensuring the long-term security of organizational changes based on optimal operational integration have considerable scientific value (Drobyazko S., 2017).

The aim of the scientific article is to develop a methodology for implementing the security of organizational changes based on optimal operational integration and its practical testing based on company cases.

The category "Organizational change" is understood very broadly, both by business and the scientific community. The range of ideas about the scale, the expected economic effect and features of the implementation of organizational change varies from "periodic changes of some functions within the existing organizational structure" to "cardinal active transformation of the system of goals, objectives, functions, organizational structure and corporate culture of the company" (Boohene, Williams, 2012). In this case, it obviously makes sense to consider two types of changes that differ in directions: planned (targeted) and unplanned (spontaneous, including "quick" changes, carried out without a predetermined system-wide goal).

\section{Methods}

The planned organizational changes should be understood as the process of the purposeful controlled transfer of the organizational system from the current state to some given (desirable), and the change planning is the formation of goals and ideas about the necessary parameters of changes (Monni, S.; Palumbo, F.; Tvaronavičienè, M., 2017; Kubeš, V; Rančák, J., 2018; Girdzijauskaite, E., Radzeviciene, A., Jakubavicius, A. 2019).

In order to ensure effective control of such a project, one should determine formal change management procedures. Goals, plans, project management, use of resources, contracts, standards used could be changed (Mullins 2005). In addition, the changes should go through five main stages: description, assessment, approval, implementation, confirmation of changes (Fig. 1).

According to one of the modern management concepts based on assessing and maximizing the value of a company and the safety of its development, organizational changes can be considered successful only if they lead to an increase in the value of the company or an increase in profitability, while both cost and profitability are understood as competitive advantages and considered as the most important control objects. Valuation of the company and its level of profitability allows us to develop a corresponding project of organizational changes based on estimated value growth or search for reserves to increase profitability of work, which positively affects the overall profitability, and can also be used as a tool for managing the process of organizational change (Cunliffe, A.L., 2008; Vinogradova, N.P., Popov, A.N., 2019; Osmyatchenko, V., Oliinyk, V., Mazina, O., Matselyukh, N., Ilin, V., Orzeł, A., 2019). 


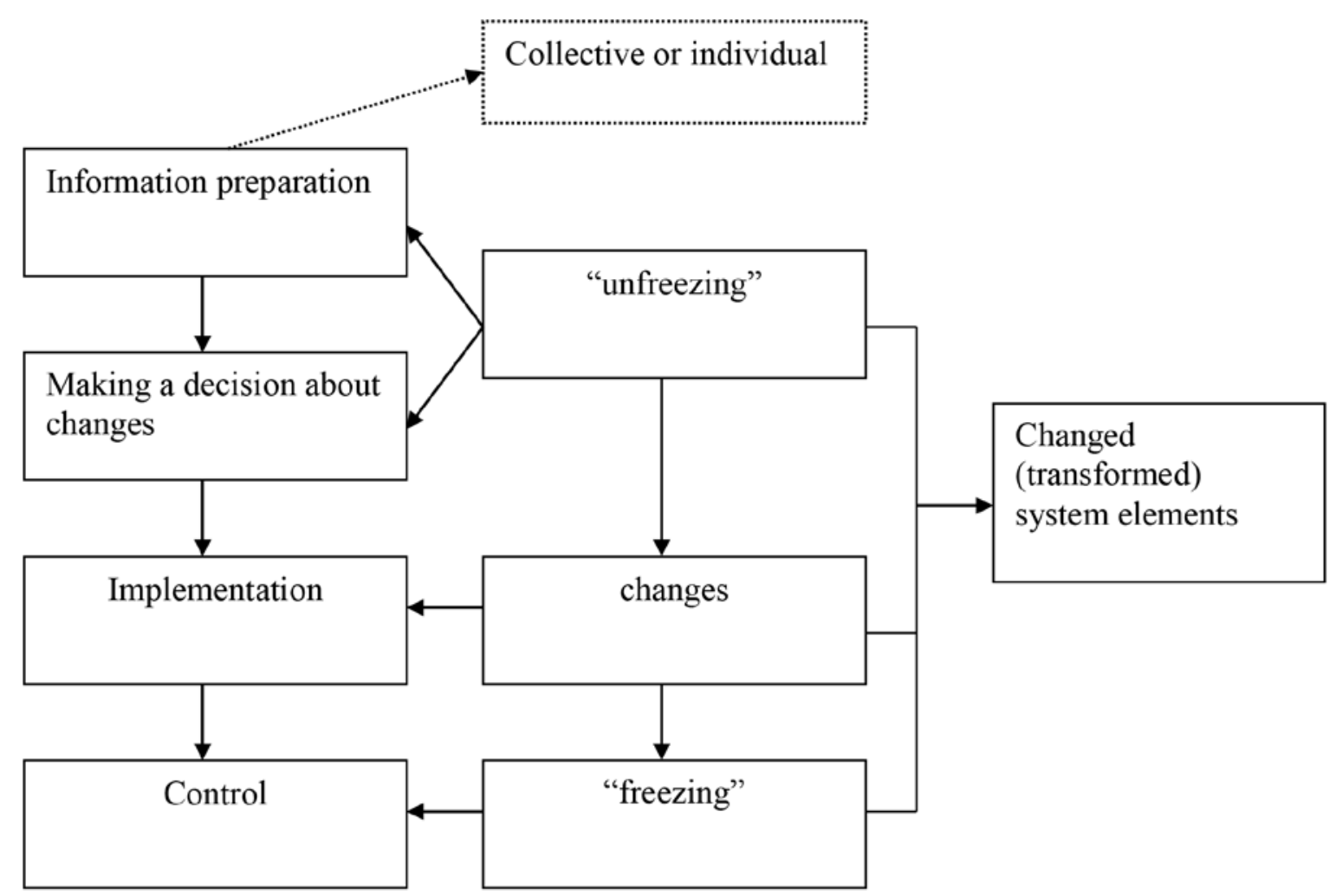

Fig. 1. Sequence of stages for the introduction of changes in a company

Source: Designed by the authors

At present, a combination of business development strategy determination and organizational change strategies is observed in the work of companies, since each of them is based on monitoring and analyzing the initial situation "as it is", forecasting and modeling possible scenarios for the company's development; sets the main goals of the changes, taking into account the potential laid down in the existing business, and determines the ways to achieve them ("as it should be").

\section{Results}

Taking into account the above, a typology of basic strategies, directions and types of changes is proposed in accordance with business development strategies:

1. Business expansion (growth) strategy. It is aimed at improving the efficiency of operations and is associated with the development of the existing company, ensuring high growth rates, including increasing competitiveness, winning new or expanding existing markets, optimizing the organizational structure, and diversifying activities (Smith \& Coy 2018).

2. Business reduction (recovery) strategy. It is aimed at financial recovery, corporate recovery, company's costs reduction in recessive conditions and its preservation.

The main directions of organizational changes in the company include: improving financial and economic activities and improving the organizational structure and management system (Tushman, Anderson 1997).

Depending on the type of structural transformations that are carried out at the enterprise, organizational changes are classified as restructuring of equity, assets, liabilities, production and management systems. The choice of strategies, directions, types of structural transformations, as well as the determination of the main tasks of management depend on the specific situation at the enterprise and the conditions for their implementation (Drobyazko S., etc., 2019). 
Improving the investment attractiveness of the company as a result of changes is the basis for planning the entire investment process: from determining future investment volumes to managing financial and business activities in order to achieve the desired capital inflow. However, for the development of domestic machine-building enterprises, it is necessary to guarantee the satisfaction of the interests not only of lenders and investors, but also of business owners, since they are among the first to experience a crisis situation in the enterprise and bear real losses of resources invested in their own capital (Goetz et. al. 2013; Makedon, Korneyev 2014b).

For an international company, the investment value is the value of the company's property complex, which is determined on the basis of its profitability from the perspective of a particular investor or group of investors, based on the company's market prospects for given investment goals. The investment value of a company can be used as a generalized indicator of the effectiveness of the management process of organizational change in a company (Servaes 1996). All other types of value in the process of organizational change can be used as an additional tool in making management decisions and applied in forecasting specific economic situations (Table 1).

Table 1. Relationship between strategies, directions of organizational change, security factor used in the valuation of the company

\begin{tabular}{|c|c|c|c|}
\hline $\begin{array}{c}\text { Change } \\
\text { strategies }\end{array}$ & Directions of change & $\begin{array}{l}\text { Types of organizational } \\
\text { transformations }\end{array}$ & Types of value \\
\hline \multirow{3}{*}{$\begin{array}{l}\text { Business } \\
\text { expansion } \\
\text { (growth) }\end{array}$} & $\begin{array}{l}\text { Improvement of financial } \\
\text { and economic activity }\end{array}$ & Restructuring of equity & \multirow{3}{*}{$\begin{array}{l}\text { Market value. Value for tax purposes. } \\
\text { Book value. Investment value } \\
\text { Internal (fundamental) value. }\end{array}$} \\
\hline & $\begin{array}{c}\text { Improvement of } \\
\text { organizational structure }\end{array}$ & Restructuring of production & \\
\hline & $\begin{array}{c}\text { Improvement } \\
\text { of management system }\end{array}$ & $\begin{array}{c}\text { Restructuring } \\
\text { of management system }\end{array}$ & \\
\hline \multirow{4}{*}{$\begin{array}{l}\text { Business } \\
\text { reduction } \\
\text { (recovery) }\end{array}$} & \multirow{3}{*}{$\begin{array}{l}\text { Improvement of } \\
\text { organizational structure }\end{array}$} & Restructuring of obligations & \multirow{4}{*}{$\begin{array}{l}\text { Market value. Investment value. } \\
\text { Mortgage value. Internal (fundamental) } \\
\text { value. Book value. Liquidation value. } \\
\text { Value for tax purposes. }\end{array}$} \\
\hline & & Restructuring of assets & \\
\hline & & Restructuring of production & \\
\hline & Improvement of management system & $\begin{array}{c}\text { Restructuring } \\
\text { of management system }\end{array}$ & \\
\hline
\end{tabular}

Source: Designed by the authors

In the practice of valuing a company, various approaches are used - costly, comparative, profit; within each of which several methods of valuation are applied, taking into account certain peculiarities of the company. A comparative analysis of the standards and methodological guidelines for business valuation suggests that the profit approach best meets the goals and objectives of organizational change, since it takes into account the interests of the investor, the level of business risk (through the discount rate) and future changes in income and expenses. In addition, it is this approach that makes it possible to correctly take into account all the changes that are planned in the process of organizational changes and the risks of economic security.

The justified strategy of organizational changes in order to comply with economic security allows choosing controllable factors that have the potential to increase the investment value (Table 2), that is, to determine the company's internal and external reserves, the "engines" of value at the current time point, since the influence of various factors on investment value of the company is uneven. 
Table 2. Factors influencing the investment value, the level of profitability and security of the company's market functioning by type of organizational change

\begin{tabular}{|c|c|}
\hline Forms of organizational change & Factors for changing investment value \\
\hline \multicolumn{2}{|r|}{ Organizational change strategies } \\
\hline Business expansion & $\begin{array}{l}\text { Amount of revenue from product sales. Volume of investments. } \\
\text { Value of raising capital. Structure of invested capital. Business growth rate. }\end{array}$ \\
\hline Business reduction & $\begin{array}{l}\text { Cost of product sales. Change in company's debt. } \\
\text { Need for net working capital. Structure of invested capital. }\end{array}$ \\
\hline \multicolumn{2}{|r|}{ Directions of organizational change } \\
\hline $\begin{array}{l}\text { Improvement of financial } \\
\text { and economic activity }\end{array}$ & $\begin{array}{l}\text { Amount of revenue from product sales. Cost of product sales. Change in company's debt. } \\
\text { Volume of investments. Value of raising capital. Business growth rate. }\end{array}$ \\
\hline Improvement of organizational structure & $\begin{array}{c}\text { Cost of product sales. Value of raising capital. } \\
\text { Business growth rate. Need for net working capital. }\end{array}$ \\
\hline Improvement of management system & $\begin{array}{l}\text { Change in company's debt. Need for net working capital. } \\
\text { Value of raising capital. Business growth rate. }\end{array}$ \\
\hline \multicolumn{2}{|r|}{ Types of organizational changes } \\
\hline Restructuring of assets & $\begin{array}{c}\text { Need for net working capital. Volume of investments. } \\
\text { Cost of product sales. Business growth rate. }\end{array}$ \\
\hline Restructuring of obligations & Change in company's debt. Need for net working capital. Structure of invested capital. \\
\hline Restructuring of equity & Volume of investments. Value of raising capital. Structure of invested capital. \\
\hline Restructuring of production & $\begin{array}{l}\text { Amount of revenue from product sales. Cost of product sales. } \\
\text { Volume of investments. Structure of invested capital. Business growth rate. }\end{array}$ \\
\hline Restructuring of management system & $\begin{array}{c}\text { Change in company's debt. Need for net working capital. } \\
\text { Value of raising capital. Business growth rate. }\end{array}$ \\
\hline
\end{tabular}

Source: Akhter 2017; Cummings \& Worley 2001; Gareis 2010

In addition, for specific directions of organizational changes and types of structural transformations, it is necessary to determine how cost and profitability change depending on changes in certain factors.

One of the most responsible stages in the process of implementing organizational changes, in the authors' opinion, is setting of tasks for departments, in other words, decomposition of the company's development goals (C) into a system of tasks, norms and requirements that are formed for each company department (U).

In the ideal case, this stage proceeds in accordance with the selected change parameters. In the corporate management system there is operational information about the current state of the company and the current results of transformations of its structure and functions. In reality, these processes take place in the conditions of (Kim et. al. 2017):

a) insufficiently reliable information, if there are errors in assessing the results of changes;

b) constraints imposed on resources (primarily human) allocated to the implementation of transformations.

In general, the principle of distribution of tasks and resources between departments assumes that each department of a company must include in the plan of its organizational transformations each of the tasks facing the entire company. By resources we understand the whole complex of means capable of ensuring the process of organizational transformations in accordance with the goals of the company: material, financial, human (labor), informational (intellectual, including production technologies, services and management), administrative (including the possibilities of delegation and redistribution of powers and responsibility) (Makedon et. al. 2019a).

This approach we will call "the principle of distributed responsibility".

Mathematically, we demonstrate this principle using a matrix $D$ : 


$$
D=\left(\begin{array}{cccccc}
d_{11} & d_{12} & \cdots & d_{1 i} & \cdots & d_{1 n} \\
d_{21} & d_{22} & \cdots & d_{2 i} & \cdots & d_{2 n} \\
\vdots & \vdots & \vdots & \vdots & \vdots & \vdots \\
d_{j 1} & d_{j 2} & \cdots & d_{j i} & \cdots & d_{j n} \\
\vdots & \vdots & \vdots & \vdots & \vdots & \vdots \\
d_{m 1} & d_{m 2} & \cdots & d_{m i} & \cdots & d_{m n}
\end{array}\right)=\left(d_{j i}\right)_{m \times n},
$$

where $d_{i j}$ - necessary intensity of solving the $i$-th task by the $j$-th department of the company, depending on the goals, as well as resource and methodological security;

$n$ - total number of goals (tasks) facing the company at this stage;

$m$ - total number of departments of the company (main, functional and auxiliary).

For example, $d_{11}$ - intensity of solving by the first department of the first task $c_{1}$ facing the company;

$d_{12}$ - intensity of the solving by the first department of the second task $\left(c_{2}\right)$, facing the company;

$d_{21}$ - intensity of the solving by the second department of the first task $\left(c_{1}\right)$ and so on.

The result of the operational planning of organizational changes, carried out in accordance with the principle of distributed responsibility, will be a system of measures $U=\left(U_{i}\right)_{m x l}$ consisting of $m$ tasks $\left(u_{1}, u_{2}, \ldots . . u_{i} \ldots u_{m}\right)$ by the number of operating departments of the company:

$$
U=\left(\begin{array}{c}
u_{1} \\
u_{2} \\
\vdots \\
u_{j} \\
\vdots \\
u_{m}
\end{array}\right)=\left(\begin{array}{c}
d_{11} c_{1}+d_{12} c_{2}+\cdots+d_{11} c_{2}+\cdots+d_{1 n} c_{n} \\
d_{21} c_{1}+d_{22} c_{2}+\cdots+d_{2 i} c_{2}+\cdots+d_{2 n} c_{n} \\
\vdots \\
d_{j 1} c_{1}+d_{j 2} c_{2}+\cdots+d_{j n} c_{2}+\cdots+d_{j n} c_{n} \\
\vdots \\
d_{m 1} c_{1}+d_{m 2} c_{2}+\cdots+d_{m i} c_{2}+\cdots+d_{m n} c_{n}
\end{array}\right)
$$

Thus, according to the methodology, the task of the first department_is presented in the form of $\left(u_{1},=d_{11} c_{1+}\right.$ $\left.d_{12} c_{2+\ldots+} d_{1 i} c_{2+\ldots} d_{1 n} c_{n}\right)$ and indicates that the organizational changes plan for this department should include all $n$ tasks $\left(\mathrm{c}_{1}, c_{2}, \ldots \ldots c_{i} \ldots c_{m}\right)$, facing the company. It is clear that the intensity $(d 11, d 12 \ldots d 1 i, d 1 n)$ of the solving each of the tasks by this department will be different and will be determined by the adopted parameters of organizational changes $(P)$.

Let's suppose that the company faces the following interrelated development tasks that ensure its adaptation to changing conditions, and the transition to a new strategic position: $c_{1}$ - product diversification; $c_{2}-$ application of the latest achievements of scientific and technical progress in the production; $c_{3}$ - formation of own sales network; $c_{4}$ - creation of a corporate culture conducive to the effective implementation of innovations in production and management.

Let's designate plans for organizational changes of departments (functional areas) of the company: $u_{1}-$ production; $u_{2}$ - HR-department; $u_{3}$ - sales department; $u_{4}-\mathrm{R} \& \mathrm{D} ; u_{5}$ - financial department; $u_{6}-$ department of marketing and advertising.

Let's consider the plan for organizational changes in the production function of the company $u_{1}=d_{11} c_{1}+d_{12}$ $c_{2}+d_{13} c_{3}+d_{14} c_{4}$.

The elements on the right side of the expression are the four parts of the plan $u_{l}$ of organizational changes carried out by the production department of the company. As can be seen, in accordance with the principle of distributed responsibility, the following intensities should be characteristic for the process of organizational changes in the 
production function of the company: $d_{11}$ - product diversification; $d_{12}$ - application of the latest achievements of scientific and technical progress in the production; $d_{13}$ - formation of own sales network; $d_{14}-$ creation of a corporate culture conducive to the effective implementation of innovations in production and management.

The first $d_{11} c_{1}$ and the second $d_{12} c_{2}$ parts of the $u_{1}$ plan can be called the "obvious tasks" of this department, while the third $d_{13} c_{3}$ and the fourth $d_{14} c_{4}$ parts indicating uncharacteristic functions for the production department are "implicit tasks".

Those parts of the transformation plans of a particular department that demonstrate the non-specific functions of this department could, alternatively, be called "non-core" or "secondary". However, the term "implicit" reflects one important feature of adaptive processes occurring in companies - the lack of the necessary coordination of actions of departments in solving new and, above all, innovative tasks for departments (Sukumaran et. al. 2015). The concentration of corporate management units on their own (obvious) tasks and their own economic security often leads to serious mismatch in joint activities. At the same time, the implementation of organizational changes in most cases requires the formulation of precisely "uncharacteristic" tasks, as well as the search for new methods for their solution and coordination of activities. For other departments (functional areas) of the company, the corresponding elements of the matrix $D$ have the same meaning, but the intensity of these processes (resource expenditure) will be different.

Thus, each department has its own plan for organizational change, and each component of such a plan is a combination of particular tasks that help to divide the overall process of change in the field of activity into its constituent elements. The concept of distributed responsibility as the most general principle of the decomposition of the tasks of organizational change is perhaps compliant with the conclusion of (Porter 2008) on the "common citizenship" of company departments.

A formal interpretation of the task distribution process when making changes should take into account the dynamism (namely, the cyclical nature) of the task distribution processes during the implementation of organizational changes. Information about the results of complex organizational changes that affect the economic characteristics and economic security of the company allows the management to quickly change the process of organizational changes. In other words, it is important to get information in time about how complex organizational changes influence the economic characteristics of a company (Sullivan, 2016). This will enable management to make timely changes to this process.

Then, taking into account feedback based on the results of transformations $(R)$ in the tasks formed for each department, it's not the strategic goals of the company's development that will be linked, but the operational information about the mismatch $\left(\Delta_{i}\right)$.

The mismatch $\left(\Delta_{i=} p_{i}, c_{i}, R, Y_{R}\right)$ should be understood as operational information that demonstrates how the results of the organizational changes made differ from the desired state, where $p_{i}$ - functional dependence, which forms the requirements for the expected results of organizational changes in the context of their compliance with the objectives of the company; $c_{i}$ - purpose of the company's development; argument $Y_{R}-$ indicates the possibility of errors in the assessment and interpretation of transformation results.

For example, if $c_{i}$ - purpose, which is to create a corporate culture that will contribute to the effective implementation of innovations in production and management, then $p_{i}$ - will set the following system of requirements: increase the level of professional competence of staff; dominance in the team of an expert leadership model; reduced bureaucracy management; formation of professional attitude to management in the departments responsible for innovation and technology.

Then the mismatch $\Delta_{i}$ will present a set of information that shows in control periods how completely and qualitatively these requirements are implemented. Taking into account the comments under consideration, the system of dynamically formed problems $U(t)$ can formally be represented as: 


$$
U(t)=\left(\begin{array}{c}
u_{1}(t) \\
u_{2}(t) \\
\vdots \\
u_{j}(t) \\
\vdots \\
u_{m}(t)
\end{array}\right)=\left(\begin{array}{c}
d_{11} \Delta_{1}+d_{12} \Delta_{2}+\cdots+d_{1 i} \Delta_{i}+\cdots+d_{1 n} \Delta_{n} \\
d_{21} \Delta_{1}+d_{22} \Delta_{2}+\cdots+d_{2 i} \Delta_{i}+\cdots+d_{2 n} \Delta_{n} \\
\vdots \\
d_{j 1} \Delta_{1}+d_{j 2} \Delta_{2}+\cdots+d_{j i} \Delta_{i}+\cdots+d_{j n} \Delta_{n} \\
\vdots \\
d_{m 1} \Delta_{1}+d_{m 2} \Delta_{2}+\cdots+d_{m i} \Delta_{i}+\cdots+d_{m n} \Delta_{n}
\end{array}\right),
$$

where the time argument $t$ indicates that the process of the formation of tasks by departments during organizational transformations is dynamic in nature, which changes.

The dynamic nature of the formation of tasks by departments shows how precisely this stage of change management is composed and responsible. However, it is just such a closed control loop that makes it possible to make adjustments to the change management process on time (Aguiar, \& Reddy 2017). The effectiveness of change management, as a result, determines the level of efficiency of management of the company's development, taking into account its impact on the external market environment.

It is obvious that the greater the number of directions of the company's activities to be transformed, the more active the organizational system's response to changes in the external environment will be (Bhatia \& Thakur 2017). However, apart from the number of attracted elements, the strength of their interaction is of great importance. In other words, the content and efficiency of transformations in a company, among other things, are determined by the type and characteristics of its structure.

What is the purpose and how should the company's departments solve the "implicit" tasks set for them? The solving "implicit" tasks by the departments allows the company to consolidate the efforts of all functional and auxiliary departments in solving common tasks. Such consolidation is possible through the rational integration of departments.

Under the current (operational) integration of units, we understand the reasonable choice of one of the possible coordination mechanisms for their interaction in the interests of effective implementation of planned organizational changes. Mathematically, the system of integration, which is the joint coordination of the efforts of the units to solve common problems, can be represented by $I$ :

$$
I=\left(\begin{array}{cccc}
i_{11} & i_{12} & \cdots & i_{1 m} \\
i_{21} & i_{22} & \cdots & i_{2 m} \\
\vdots & \vdots & \cdots & \vdots \\
i_{m 1} & i_{m 2} & \cdots & i_{m m}
\end{array}\right) .
$$

As you can see, the integration matrix is square $m \times m$, where $m$ is the number of functional departments of the company.

Let's form a meaningful content of the elements of the proposed matrix: $i_{l 1}$ - internal integration (coordination) efforts of the first department, aimed at ensuring the high efficiency of its own ("obvious") part of organizational transformations; $i_{12}$ - integration (coordination of activities) of the first and second departments, carried out in the interests of organizational transformations of the first department; $i_{21}$ - integration (coordination of activities) of the first and second departments, carried out in the interests of organizational transformations of the second department. 
Within the framework of the above case model: $i_{11}$ - internal integration (coordination) efforts of the production department, aimed at ensuring high efficiency of the process of updating production equipment or technologies; $i_{12}$ - integration of the production department and HR-department (in the interests of production), aimed at coordination and joint formulation of requirements for production personnel (workers, technologists, engineers).

The coordinated work of these two departments, for example, may allow the production department to avoid the need to recruit insufficiently qualified specialists.; $i_{2}$ is also coordination of activities of the production department and HR department (in the interests of the HR department), aimed at coordination and joint formulation of requirements for production personnel. The integration of these two departments allows the HR department to avoid wasting time and other resources on finding and hiring personnel, production department that does not fully meet the requirements (Isom \& Tiemann 2014).

In other words, the integration matrix is a system of horizontal coordination of the process of solving common tasks of a company. Meaningfully, the integration matrix is a table that quantitatively describes the density of interaction between departments when solving problems of organizational change (Table 3). The strength of the department interaction can be assessed by arbitrary units in the range from " 0 " (complete lack of interaction) to " 1 " (the maximum possible interaction).

Table 3. Strength of the company's department interaction (case example)

\begin{tabular}{|c|c|c|c|c|}
\hline \multirow{2}{*}{$m$} & \multicolumn{4}{|c|}{ Functional directions } \\
\cline { 2 - 5 } & Production & Finance & Marketing & Personnel \\
\hline Production & $\mathbf{1}$ & 0,5 & 0,2 & 0,1 \\
\hline Finance & 0,5 & $\mathbf{1}$ & $\mathbf{1}$ & 0,2 \\
\hline Marketing & 0,2 & 0,7 & 0,2 & $\mathbf{1}$ \\
\hline Personnel & 0 & 0,1 & & 0 \\
\hline
\end{tabular}

Source: Designed by the authors

This case demonstrates an option of the operational state of the company's organizational structure, in which its production departments do not practically interact with the HR department $\left(i_{14}=i_{41}=0\right)$; the strength of the interaction of the financial and production departments can be called the average $\left(i_{12}=i_{21}=0,5\right)$, and the financial and marketing functional areas interact "more closely" $\left(i_{23}=i_{32}=0,7\right)$. The strength of the internal integration of each department is assessed as " 1 " (diagonal cells of the matrix).

The principle of distributed responsibility in combination with the principle of integration of departments and compliance with the requirements of economic security, according to the authors, represents the most general model of the distribution of tasks during organizational changes. However, this approach can hardly be called widespread in business practice. Most modern companies have a functional or linear-functional structure with the number of hierarchy levels from two to six (Chakrabarti \& Mitchell 2004). One of the main drawbacks of such structures is the misunderstanding by the management of the functional departments of the overall objectives of the company. The phrase "misunderstanding" indicates here not so much the lack of information for middle management about the general direction of the company's development, but rather about the presence of conditions that encourage management to focus only on the "obvious" tasks of its departments without taking into account the necessary level of integration with other departments.

A large number of hierarchy levels with a high centralization of management leads to a decrease in the integration activity of the managers of functional and auxiliary departments, since they do not have the authority to make independent decisions. Decentralization and the presence of informal horizontal links make it possible to partially eliminate this disadvantage. Thus, close interaction is characteristic for matrix and multidimensional structures. However, the unjustified intensification of information exchange between parts of an organization or the unreasonable concentration of powers in one part of a company often not only does not eliminate contradic- 
tions, but also strengthens them. In some cases, it is the simplification of internal functional relationships that leads to an increase in the level of economic security and managerial stability.

It is obvious that such an understanding of the role of integration between parts (business functions) of a company allows us to formulate an assumption about some optimal interaction in the implementation of organizational changes. Since operational integration has a dynamic nature, this circumstance makes it possible to consider management of organizational changes as a process of forming operational (temporary) organizational structures, the composition and nature of relations within which is optimal precisely for this (current) stage of management of organizational changes. In such a statement, the criterion for the optimality of such temporary structures is the minimum value of the mismatch $\left(\Delta_{i}\right)$.

According to such a matrix model, elementary organizational changes $d R$ is an additive-multiplicative connection of such factors as the tasks facing the departments and the degree of their coordination (integration):

$$
d R=\left(\begin{array}{c}
d r_{1} \\
d r_{2} \\
\vdots \\
d r_{j} \\
\vdots \\
d r_{m}
\end{array}\right)=I \times U=\left(\begin{array}{cccccc}
i_{11} & i_{12} & \cdots & i_{1 j} & \cdots & i_{1 m} \\
i_{21} & i_{22} & \cdots & i_{2 j} & \cdots & i_{2 m} \\
& & & \vdots & & \\
i_{j 1} & i_{j 2} & \cdots & i_{j j} & \cdots & i_{j m} \\
& & & \vdots & & \\
i_{m 1} & i_{m 2} & \cdots & i_{m j} & \cdots & i_{m m}
\end{array}\right) \times\left(\begin{array}{c}
u_{1} \\
u_{2} \\
\vdots \\
u_{j} \\
\vdots \\
u_{m}
\end{array}\right),
$$

where based on matrix transformation $\left(d r_{j}=i_{j 1} u_{1+} i_{j 2} u_{2+\ldots+} i_{j j} u_{j+\ldots+} i_{l m} u_{m}\right)$. That is, in the most general case, any elementary organizational change $d r_{j}$ is implemented in the $j$-th department and is the result of the work of all departments of the organization thanks to the coordination of their activities in the interests of the $j$-th department.

It is obvious that the type and depth of integration of each department with each of the other departments of the company should depend on the nature, complexity and urgency of the jointly solved tasks. The effectiveness of each elementary organizational change implemented in the company's departments depends on the effectiveness of the solution of this task by all departments of the company in the most favorable integration of all departments in order to solve this problem.

What types of coordination mechanisms and ways to integrate departments should be considered the most effective for making organizational changes? What is meant by optimal integration? It seems that in order to receive answers to these questions, it is necessary, first, to analyze all possible coordination mechanisms and conditions, and second, to determine the optimal integration criteria for various models of organizational change. 
Table 4. Forms of organizational interaction, involving various measures of coordination

\begin{tabular}{|c|c|c|c|}
\hline \multirow{2}{*}{$\begin{array}{c}\text { Strength of integration } \\
\text { (conditional } \\
\text { coefficient) }\end{array}$} & $\begin{array}{c}\text { Forms of organizational interaction } \\
\text { groups and individuals }\end{array}$ & $\begin{array}{c}\text { across functional areas } \\
\text { and company business units }\end{array}$ & $\begin{array}{c}\text { across group-wide } \\
\text { organizational forms }\end{array}$ \\
\cline { 2 - 5 } $\begin{array}{c}\text { 1. Maximum } \\
\text { integration }(0,8-1,0)\end{array}$ & Work teams & $\begin{array}{c}\text { Adhocracy (matrix and project structures, a significant } \\
\text { flow of informal communications). Mutual coordination }\end{array}$ & $\begin{array}{c}\text { Combines, vertically } \\
\text { integrated structures }\end{array}$ \\
\hline $\begin{array}{c}\text { 2. High integration } \\
\text { level }(0,6-0,8)\end{array}$ & $\begin{array}{c}\text { Permanent Integrators } \\
\text { Linking Positions }\end{array}$ & $\begin{array}{c}\text { Simple structure (centralization, a significant flow } \\
\text { of informal communications). Direct control }\end{array}$ & $\begin{array}{c}\text { Concerns, financial- } \\
\text { industrial groups }\end{array}$ \\
\hline $\begin{array}{c}\text { 3. Average integration } \\
\text { level }(0,4-0,6)\end{array}$ & $\begin{array}{c}\text { Temporary working } \\
\text { teams, standing } \\
\text { committees }\end{array}$ & $\begin{array}{c}\text { Professional bureaucracy (a significant flow } \\
\text { of informal communications at the core level). } \\
\text { Standardization of qualification }\end{array}$ & Holdings \\
\hline $\begin{array}{c}\text { 4. Low integration } \\
\text { level }(0,2-0,4)\end{array}$ & $\begin{array}{c}\text { Temporary direct } \\
\text { contacts }\end{array}$ & $\begin{array}{c}\text { A. Mechanistic bureaucracy (functional structure, weak } \\
\text { informal communications). Standardization of labor. } \\
\text { B. Divisional structures. Standardization of output. }\end{array}$ & $\begin{array}{c}\text { Conglomerates, } \\
\text { consortia, cartels, } \\
\text { subsidiaries }\end{array}$ \\
\hline $\begin{array}{c}\text { 5. Extremely low } \\
\text { integration level } \\
(0,0-0,2)\end{array}$ & $\begin{array}{c}\text { Information systems } \\
\text { remote employees } \\
\text { (freelancers) }\end{array}$ & Outsourcing & Franchising \\
\hline
\end{tabular}

Source: Designed by the authors

The scientist (Mintzberg 2007) identifies five coordination mechanisms through which companies coordinate their activities: mutual coordination, direct control, standardization of work processes, standardization of output, standardization of skills and knowledge (qualifications). In some cases, to achieve the necessary nature of coordination of departments, five coordination mechanisms are not enough. As a rule, companies develop integrated tools that provide the necessary level of interaction between individual employees and departments. It is possible on the basis of generalization of these classifications to allocate five degrees of integration for various forms (scales) of organizational interaction (Table 4).

Operational integration activity and integration capabilities of departments. Conducting organizational changes in a company requires various integration activities of its parts. The integration activity of a department should be understood as its desire to combine resources with resources (primarily intellectual and informational) of other departments. At the same time, the desire to attract the resources of other departments to solve "their own" (formerly "implicit" tasks) is called the "internal integration activity" of the department, and the desire to participate in solving the tasks of other departments - "external integration activity" (Thakor 2003).

The set of integration activities of departments generates the property of organizational convergence. The required degree (type) of the integration activity of department should be determined on the basis of a formalized view of the criteria for the effectiveness of organizational transformations.

For example, the desired degree of integration activity during a reactive (that “overtakes") organization's adaptation to changes in the external environment can be determined based on the condition of ensuring the smallest current deviations of the organization's state from the requirements dictated by changes in its environment ("mismatches" $\left(\Delta_{i}\right)$.

As shown in [8], the management of reactive adaptation by the criterion of minimum expectation and mismatch requires consideration of the rate of change of the external environment and the level of information uncertainty:

$$
K_{o p t}=\sqrt{\frac{2 m_{v}}{Q}}
$$

where $K_{\text {opt }}$ - optimal (by the criterion of the minimum probability characteristics of the mismatch) level of adaptation intensity, provides for the integration activity of the departments; 
$m_{V}$ - average (over the observation period) rate of change of the external environment (in the field of department responsibility);

$Q$ - level of information uncertainty of the state of the external environment (dispersion of assessments).

As can be seen, an increase in the level of information uncertainty of processes, the management of which falls within the scope of responsibility of the company, leads to the need to reduce the strength of its coordination (integration) activity. In addition, different departments have different adaptation potentials due to the specifics of their factors.

These conditions force the units to respond to changes in the external environment at different speeds, which, in turn, causes disintegration in the work of the entire organization. According to a well-known specialist in the field of organizational change management (Adizes 1991) "Any change causes disintegration".

In this world, everything consists of systems. Systems, in turn, consist of subsystems that cannot respond to changes at the same rate. There are "gaps" between the subsystems (George \& Jones 2007).

In the framework of "catching up" adaptation, an increase in integration and, as a result, the elimination of coordination "gaps" between departments is possible only by reducing each department's "own" level of information uncertainty. At the same time, the "artificial" integration due to the "forced" coordination of the activities of the departments will only lead to the organization deviating from the given trajectory of organizational changes, causing an increase in the variance of the mismatch, making the process of producing results random. Figuratively speaking, "forced" coordination of department, which structural and functional parameters are characterized by a high level of information uncertainty, with other departments will lead to the formation of unreliable information in the organization of circulation channels (Gilbert 2017).

As can be seen, the implementation of reactive organizational changes leads to a very destructive contradiction: the desire of the management of individual departments to integrate to reduce the level of information uncertainty turns into an increase in the overall organizational level of information uncertainty.

\section{Discussion}

Strictly speaking, an increase in the level of information uncertainty should lead to a decrease not in the integration needs of the department, but in its integration capabilities, in other words, in its integration powers. The integration capabilities of a department should be understood as the degree and nature of its interaction with other departments of the organization, justified on the basis of a formalized idea of the effectiveness of organizational changes and the directives established for this department.

One of the primary tasks of the preparation and implementation of organizational changes is the justification and optimization of the integration powers of all departments of the company, which is a process of dynamic optimization of the organizational structure of the company (Ye et. Al. 2017). At the same time, the criterion for dynamic optimization of an organizational structure is understood as the most complete correspondence of the organizational structure to the goals and objectives of the changes. Thus, in the course of organizational changes, the task of operational optimization of the integration powers of departments is the process of forming "operational-optimal" organizational structures that most contribute to the implementation of changes in other (non-structural) aspects.

Various integration powers and the corresponding integration activities of the departments generate temporary change control centers, and the company's organizational structure is temporarily likened to a network structure.

An illustrative example (Table 5) demonstrates one of the possible options for the distribution of activities and the formation of temporary centers for change management. 
Table 5. Operational distribution of integration powers (case example)

\begin{tabular}{|c|c|c|c|c|c|}
\hline Company's department & Department 1 & Department 2 & Department 3 & Department 4 & Department 5 \\
\hline Department 1 & 1,00 & 0,75 & 0,90 & 0,85 & 0,70 \\
\hline Department 2 & 0,00 & 1,00 & 0,85 & 0,95 & 0,00 \\
\hline Department 3 & 0,30 & 0,40 & 1,00 & & 0,10 \\
\hline Department 4 & 0,00 & 0,80 & 0,75 & 1,00 & 0,30 \\
\hline Department 5 & 0,10 & 0,00 & 0,60 & 0,00 & 1,00 \\
\hline
\end{tabular}

Source: Designed by the authors

Such a distribution indicates, for example, that department 1 (see the first row of Table 5) becomes a temporary center for change management, attracting resources from all departments to solve problems in the form of creating joint work teams and attracting integrators. At the same time, department 3 (see the third column of Table 5), being "demanded" as much as possible, is forced to delegate its own resources in the interest of solving the tasks of other departments.

It is worth making this observation. Integration capabilities, which are determined analytically or distributed by the company's management in a different way, are only requirements or recommendations themselves. However, in the process of implementing organizational changes, perhaps, we should expect the desire of the departments to increase the "internal" and decrease the "external" integration activities, which will lead to an increase in corporate convergence. As a result, such a "redistribution of integration powers" can lead to a deviation from the optimal trajectory of managing organizational changes, reducing the predictability of their results and adversely affect the economic security of the company. However, this methodology is positive and organizationally reasonable, which indicates the possibility of its practical application in the environment of production companies.

\section{Conclusions}

It was proved that the methodological approaches to changes in the work of companies should be based on the principles of consistency, complexity and functionality. The implementation of these principles should occur through the following possible types of organizational change, such as: 1. unplanned changes, which should be a reaction of the enterprise to any events and trends that may be threatening or, conversely, provide unexpected new opportunities; 2. planned changes - willingness to react at the right time for favorable opportunities or problems in accordance with the goal of the most complete use or maximum leveling of the impact; 3 . imposed changes that occur under the influence and on the initiative of the management of the enterprise in order to adequately respond to urgent situations or events; 4. integration changes that are aimed at increasing the "internal" and reducing the "external" integration activities, which will lead to an increase in the level of functional interaction.

\section{References}

Adizes, I. (1991). Mastering Change: The Power of Mutual Trust and Respect in Personal Life, Family Life, Business and Society. Santa Monica, California: Adizes Institute Publications. URL: https://www.stevezuieback.com/pdf_systems/masteringchange.pdf

Aguiar, E., \& Reddy, Y.V. (2017). Corporate diversification on firm's financial performance: An empirical analysis of select FMCG corporations in India. Management Today, 7(4), 194-205 URL: http://irgu.unigoa.ac.in/drs/handle/unigoa/5071

Akhter, F. (2017). Unlocking digital entrepreneurship through technical business process. Entrepreneurship and Sustainability Issues, 5(1), 36-42. https://dx.doi.org/10.9770/jesi.2017.5.1(3)

Bhatia, A., \& Thakur, A. (2017). Choice of diversification strategies in an emerging market environment: An empirical evaluation. International Journal of Business and Globalization, 19(1), 52-78. † https://dx.doi.org/10.1504/IJBG.2017.085108

Bhojraj, S., Sengupta, P. (2003). The Effect of Corporate Governance Mechanisms on Bond Ratings and Yields: The Role of Institutional Investors and Outside Directors, Journal of Business, 76(3): 455-475. https://dx.doi.org/10.1086/344114 
Boohene, R. \& Williams A.A. (2012). Resistance to organizational change: A case study of Oti Yeboah Complex Limited. International Business and Management, 4(1), 135-145. https://dx.doi.org/10.3968/j.ibm.1923842820120401.1040

Cawsey, T. \& Deszca, G. (2007). Toolkit for organizational change. Thousand Oaks, CA: Sage.

Chakrabarti, A., \& Mitchell, W. (2004). A corporate level perspective on acquisitions and integration. In Advances in Mergers and Acquisitions: Emerald Group Publishing Limited. URL: https://www.emeraldinsight.com/doi/abs/10.1016/S1479-361X\%2804\%2904001-3

Cunliffe, Ann L. (2008). Organization Theory. Sage Course Companions

Cummings, T.G., \& Worley, C.G. (2001). Organization Development and Change. Cincinnati, OH: South-Western College Publishing. URL: http://www.mcs.gov.kh/wp-content/uploads/2017/07/Organization-Development-and-Change.pdf

Drobyazko S. (2017). Formation of competitive positions as providing of economic security of insurance companies // International scientific journal "Internauka”. Series: "Economic Sciences”, №2. URL: https://doi.org/10.25313/2520-2294-2017-2-4784

Drobyazko S., Hryhoruk I., Pavlova H., Volchanska V., Sergiychuk S. (2019). Entrepreneurship innovation model for telecommunications enterprises. Journal of Entrepreneurship Education, 22, 2 URL: https://www.abacademies.org/articles/entrepreneurship-innovation-model-for-telecommunications-enterprises-8097.html

Gareis, R. (2010). Changes of organizations by projects, International Journal of Project Management, 28, 317-327. https://dx.doi. org/10.17722/ijme.v2i3.101

George, J.M., \& Jones, G.R. (2007). Understanding and Managing Organizational Behavior (5rd). New York: Pearson Education, Inc.

Gilbert, E. (2017). Militaries, finance, and (in)security. Finance and Society, 3(2), 180-187. https://doi.org/10.2218/finsoc.v3i2

Girdzijauskaite, E., Radzeviciene, A., Jakubavicius, A. (2019). Impact of international branch campus KPIs on the university competitiveness: FARE method. Insights into Regional Development, 1(2), 171-180. https://doi.org/10.9770/ird.2019.1.2(7)

Goetz, M.R., Laeven, L., \& Levine, R. (2013). Identifying the valuation effects and agency costs of corporate diversification: Evidence from the geographic diversification of US banks. The Review of Financial Studies, 26(7), 1787-1823. URL: https:/econpapers.repec.org/scripts/redir.pf?u=http\%3A\%2F\%2Fhdl.handle.net\%2F10.1093\%2Frfs\%2Fhht021;h=repec:oup:rfinst:v:26:y:2013:i:7 :p:1787-1823

Isern, J., \& Pung, A. (2007). Harnessing energy to drive organizational change. McKinsey Quarterly, 1, 16-19. URL: https://pdfs.semanticscholar.org/0bce/ee171bb2b25af0fd00d574330e69262f71bb.pdf

Isom, Phil \& Tiemann, Dan (2014). M\&A Growth Strategy: A New Approach for Transforming Businesses. Abfjournal, Available at: http://www.abfjournal.com/articles/ma-growth-strategy-a-new-approachfor-transforming-businesses/

Kim, H., Hong, S., Kwon, O., \& Lee, C. (2017). Concentric diversification based on technological capabilities: Link analysis of products and technologies. Technological Forecasting and Social Change, 118, 246-257. † http://dx.doi.org/10.1016/j.techfore.2017.02.025

Kotter, J.P. (2012). Leading Change, Harvard Business School Review: 18-19

Kubeš, V; Rančák, J. (2018). Sustainability of organization performance via management techniques. Entrepreneurship and Sustainability Issues, 5(4), 1031- 1042. http://doi.org/10.9770/jesi.2018.5.4(23)

Makedon, V., Drobyazko, S., Shevtsova, H., Maslosh, O., Kasatkina, M. (2019a). Providing security for the development of hightechnology organizations. Journal of Security and Sustainability Issues, 8(4), 1313-1331. https://doi.org/10.9770/jssi.2019.8.4(25)

Makedon, V., Korneyev, M. (2014b). Improving methodology of estimating value of financial sector entities dealing in mergers and acquisitions. Investment Management and Financial Innovations, 11(1), 44-55.

Mintzberg, H. (2007). Tracking Strategies: Toward a General Theory, OUP Oxford

Monni, S., Palumbo, F., Tvaronavičienė, M. (2017). Cluster performance: an attempt to evaluate the Lithuanian case. Entrepreneurship and Sustainability Issues, 5(1), 43-57. https://doi.org/10.9770/jesi.2017.5.1(4)

Mullins, L.J. (2005). Management and organizational behavior. Harlow, England; New York: Prentice Hall/Financial Times.

Osmyatchenko, V., Oliinyk, V., Mazina, O., Matselyukh, N., Ilin, V., Orzeł, A. (2019). The influence of the global technological changes on principles and functions of accounting and formation of the organization strategy. Journal of Security and Sustainability Issues, 8(4), 631-641. https://doi.org/10.9770/jssi.2019.8.4(7) 
Share: FacebookGoogle+LinkedInTwitter

Porter, M.E. (2008). The Five Competitive Forces That Shape Strategy”, Harvard Business Review, (1): 79-93.

Sams, Andre Yee. (2001). Integrating Your e-Business Enterprise, Paperback, Published March

Servaes, H. (1996). The value of diversification during the conglomerate merger wave. The Journal of Finance, 51(4), 1201-1225. URL: http://faculty.london.edu/hservaes/jf1996.pdf

Smith, G.C., \& Coy, J.M. (2018). Corporate diversification: Can the observed diversification discount shed light on management's choice to diversify or re-focus? Review of Accounting and Finance, 17(3), 405-424. † https://doi.org/10.1108/RAF-11-2016-0172

Sukumaran, A., Gupta, R., \& Jithendranathan, T. (2015). Looking at new markets for international diversification: frontier markets. International Journal of Managerial Finance, 11(1), 97-116. https://doi.org/10.1108/IJMF-05-2013-0057

Sullivan, Martin A., (2016). Economic Analysis: Cut the Corporate Rate or Integrate? Tax Notes 150 (January 11): 156-176. URL: https://ntanet.org/NTJ/69/3/ntj-v69n03p677-700-integration-corporate-shareholder-taxes.pdf?v=\%CE\%B1

Thakor, A.V. (2003). Corporate Investment and Finance. Financial Management, 22(2), 135-144. https://dx.doi.org/10.2139/ssrn.796988

Tushman, M. L., Anderson P. (1997). Managing Strategic Innovation and Change, Oxford

Vinogradova, N.P., Popov, A.N. (2019). Methodological basis of economic decision-making. Entrepreneurship and Sustainability Issues, 6(4), 1798-1806. http://doi.org/10.9770/jesi.2019.6.4(18)

Wit, B., Meyer, R. (2005). Strategy Synthesis. Resolving strategy. Paradoxes to Create Competitive Advantage. Thomson Learning

Ye, M., Lu, W., Ye, K., \& Flanagan, R. (2017). How do top construction corporations diversify in the international construction market? In Proceedings of the 20th International Symposium on Advancement of Construction Management and Real Estate (pp. 101-110). Springer, Singapore. đURL: https://hub.hku.hk/bitstream/10722/223958/1/Content.pdf?accept=1

Zahavi, T., \& Lavie, D. (2013). Intra industry diversification and firm performance. Strategic Management Journal, 34(8), 978-998. https://doi.org/10.1002/smj.2057

Svetlana DROBYAZKO, PhD in Economics, Professor European academy of sciences, Coventry, United Kingdom ORCID ID: orcid.org/0000-0003-2022-0126

Olena POTYSHNIAK, Doctor of Economic Sciences, Associate Professor of Management, Professor of the Department of Organization of Production, Business and Management of Kharkiv Petro Vasylenko National Technical University of Agriculture ORCID ID: orcid.org/0000-0002-3434-6208

Natalia RADIONOVA, Ph.D (Economics), Associate Professor of the Departmen Kyiv National University of Technologies and Design

ORCID ID: orcid.org/0000-0002-8855-2963

Serhii PARANYTSIA, Candidate of Juridical Sciences, Associate Professor, National University of the State Fiscal Service of Ukraine RCID: ID: orcid.org/0000-0001-7907-1220

Yuliia NEHODA, Ph.D., Associate Professor of the Department of Finance National University of Life and Environmental Sciences of Ukraine

ORCID ID: orcid.org/0000-0002-9714-5438 